\title{
A cross-linguistic analysis of the "homework" metaphor in German and English political discourse
}

Discourse \& Society

():1-22

(C)The Author(s)

Reprints and permission:

sagepub.co.uk/journalsPermissions.nav DOI: 10.1177/0957926518802916 www.sagepub.com/

(3)AGE

\section{Mario Bisiada}

\begin{abstract}
A frequently encountered expression in political discourse across languages is the assertion that someone has not "done their homework". As the expression is a combination of structural metaphor and understatement, it is a figurative frame that simplifies public debates by presenting complex issues such as economic reforms as simple tasks and stifles critical and consensual political debates by replacing questions of fairness and adequacy with unquestionable moral obligation. In spite of this manipulative force, metaphor research has paid little attention to this metaphor. I investigate its emergence and pragmatic effects in American and German newspaper discourse through the COHA/COCA and Die ZEIT corpora. Findings for both English and German show that, while the metaphor was originally used for positive self- and negative other-representation, it is now used increasingly often without specifying whether or not someone has done their homework, which is evidence to suggest that it has become accepted in public discourse as a normal way of framing political issues.
\end{abstract}

\section{Keywords}

framing, homework, metaphor, political discourse, public debate, evaluation, mitigation, journalism

\section{Introduction}

The expression "to do one's homework" is recurrent in both spoken and written political discourse. It was used widely in recent US presidential election campaign speeches,

Post-print version - please cite as:

Bisiada, Mario. 2018. A cross-linguistic analysis of the "homework" metaphor in German and English political discourse. Discourse \& Society. Online first. doi:10.1177/0957926518802916 
for instance when Hillary Clinton accused Bernie Sanders of not having "done his homework" (5 April 2016), or when Barack Obama said about Clinton that "she has worked tirelessly and diligently. She has done her homework. She has performed." (14 October 2016). However, this metaphor is not new in political discourse, but was already widespread in the 1960s, as example (1) demonstrates.

(1) Some of us on this side of the Committee, if I may employ the now conventional expression, "having done our homework", know that the method he proposes for achieving the result we all want to see is not practicable. (HANSARD, 3 December 1964, emphasis mine)

The expression is also used in other languages such as Spanish ("hacer los deberes") and German ("seine Hausaufgaben machen"). It is not just applied to individuals, but also to countries or entire populations, as in examples (2-4).

(2) Es hora de que algunos dirigentes europeos piensen que hacer los deberes no sólo es algo que atañe a los países del sur, sino a todos. (El País, 12 October 2014)

['It's time that some European leaders realised that doing homework is not only an issue for countries of the south, but for everyone.']

(3) Die Griechen müssen ihre Hausaufgaben machen. Athen profitiert von Milliardenhilfen über die Rettungspakete. Die Griechen haben keinen Grund zur Klage. Sie hätten allen Grund, jetzt die Reformen anzupacken, um ihr Land auf Kurs zu bringen. (Government spokesman Volker Kauder interviewed by Rheinische Post, 23 June 2012)

['The Greeks must do their homework. Athens is benefitting from billions' worth of help via the rescue packages. The Greeks have no reason to complain. They would have every reason to tackle the reforms to bring their country on track now.']

(4) Die arabische Welt hat jahrhundertelang ihre Hausaufgaben nicht gemacht. (Focus Magazin, $\mathrm{Nr}$ 28/2015)

['The Arabic world hasn't done its homework for centuries.']

In this fashion, the "Hausaufgaben" metaphor has enjoyed popularity among German politicians when talking about Greece in the EU. Their consistent demands that the Greeks should "do their homework", as exemplified by (3) above, have led to criticism and ridicule of this expression in political contexts in the press (Kemper, 2016). Schuler (2015) notes its popularity even among proponents of rescue packages for Greece, criticising the understatement implicit in this diction:

Ganz abgesehen von dem arrogant-schulmeisterlichen Ton: Kann man wirklich von Hausaufgaben reden, wenn man einem Land ein derart einschneidendes Reformpaket abverlangt? (Schuler, 2015) 
['Leaving aside the arrogant and schoolmasterly tone: can we really talk about homework when we demand such a drastic package of reforms from a country?'] (my translation)

As a result, the "Hausaufgaben" metaphor was among the candidates for the 2015 Unwort des Jahres campaign, which each year selects the most notorious word in order to cast light on expressions that are used frequently but go against objective adequacy and humaneness (Janich, 2015). In the case of the "homework" metaphor, the jury argued that its proliferant use degrades democratically elected governments to disenfranchised school children and violates principles of democratic coexistence in Europe (Janich, 2015).

But despite the extensive use of the "homework" metaphor in political discourse in a variety of languages, metaphor research has so far paid no attention to it. There are plenty of cross-linguistic studies of metaphor in discourse, especially on metaphors of the recent economic crisis (Charteris-Black and Ennis, 2001; Charteris-Black and Musolff, 2003; Herrera Soler, 2008; Rojo López and Orts Llopis, 2010; Semino, 2002; for an overview of cross-linguistic studies of metaphor, see Deignan, 2005: 99-101; see also Arrese, 2015: 21-23), but none of them features this metaphor.

In this paper, I want to contribute such a study. I argue that the "homework" metaphor is a complex figurative frame (Burgers et al., 2016), as it combines two figurative language devices: metaphor and meiosis (understatement). Meiosis has received little attention in metaphor research (Kreuz et al., 1998: 93), as have combinations of figurative language devices (Burgers et al., 2016: 419). The "homework" metaphor warrants in depth study because it is an example of both. In addition, over its many years of existence, it seems to have become increasingly meiotic, evidenced by its application no longer just to individuals, but even to entire civilizations, as a comparison of old examples such as (1) and recent examples (2-4) and (5) show.

(5) "The West that preaches human rights hasn't done its homework," says James O'Dea, director of Amnesty International's Washington office. (Christian Science Monitor, 10 June 1993)

This paper thus aims to be an initial cross-linguistic, corpus-aided investigation of the "homework" metaphor. I analyse the emergence of the figurative use of the expression and study its evaluative context in American newspapers contained in the corpora of historical and contemporary American English (COHA/COCA) and in the German newspaper Die ZEIT.

Based on this study, I argue that the use of the "homework" metaphor shapes and manipulates public debates by establishing unequal power relations between the actors involved in current issues. If metaphors "encode particular ideological positions through the relationships that they suggest between entities, and through their entailments" (Deignan, 2005: 131), a metaphor that suggests a teacher-pupil relation between interlocutors would seem especially ideologically laden. However, such metaphors from the source domain of education, to which the "homework" metaphor belongs and from 
which are drawn a range of other metaphors with similar effects, have hitherto not received the attention they deserve in the area of metaphor research.

\section{"Doing homework" as a figurative frame}

The word Hausaufgabe is defined in the Duden dictionary only in its literal meaning as "vom Lehrer, der Lehrerin aufgegebene Arbeit, die die Schülerinnen und Schüler zu Hause erledigen müssen". The entry for the English word homework in the MerriamWebster dictionary has, as the first meaning, "piecework done at home for pay", followed by the school-related meaning "an assignment given to a student to be completed outside the regular class period". As the third meaning, it defines homework as "preparatory reading or research (as for a discussion or a debate)". Similarly, the Oxford English Dictionary (OED) has as the first definition "work done at home, esp. as distinguished from work done in a factory", with the school-related use context as the second meaning: "Schoolwork assigned to a pupil to be done outside lesson time (typically at home)".

The OED also defines an extended use, "an assignment or exercise to be completed in one's own time", and defines the phrase to do one's homework as meaning "to prepare thoroughly for an event or situation; to brief oneself in preparation for a meeting or discussion". It lists a quote from the N.Y. Tribune from 1915 as its first occurrence ("The Phillies have done their home work well, but it is the Braves who have again become most prominently mentioned as the final winners." Entry P1, http://www.oed.com/view/Entry/87951). Unlike the German word, then, the English word is not restricted to a school context and may thus be considered "conventionalised" (Deignan, 2005: 47) as a metaphor.

The only scientific study of the "homework" metaphor to my knowledge was conducted by Arrese (2015) on the use of metaphors in Spanish press coverage of the European sovereign debt crisis, in which he includes the Spanish expression "hacer los deberes". In the Spanish dictionary published by the Royal Academy of Spanish (dle.rae.es), deberes is defined as an "ejercicio que, como complemento de lo aprendido en clase, se encarga, para hacerlo fuera de ella, al alumno de los primeros grados de enseñanza"2.

Arrese (2015) studies data from the daily newspapers ABC, El Mundo, El País and Expansión, analysing the metaphorical source domains disease, nature, mechanics, war, sport and organism. Among the latter category, he includes "hacer los deberes", and defines the category as "actions and situations of living beings" (Arrese, 2015: 25). This category, which he admits to be "quite miscellaneous" (Arrese, 2015: 29), contains nine other metaphors. They include "talón de Aquiles" ("Achilles heel'), "un plan sin cocinar" ('uncooked plan') and "los mercados se duermen" ('markets fall asleep') (Arrese, 2015: 28).

In his analysis, the most common category in all of the four newspapers under analysis is disease, followed by organism and nature (Arrese, 2015: 29). The finding that the crisis is talked about predominantly using natural metaphors is supported by cross-linguistic research (Cortés de los Ríos, 2010; O’Mara-Shimek et al., 2015). While this potentially indicates a frequent use of the "hacer los deberes" metaphor, no individual counts for 
each metaphor are provided and the catch-all nature of the organism category makes it hard to draw more specific conclusions for the use of the "hacer los deberes" metaphor.

The "homework" metaphor may be labelled what Lakoff and Johnson (1980) call a structural metaphor. The expression "doing one's homework" may serve as a way of referring to complex economic or political tasks as something someone should have done to prepare for a given event. In other words, by employing a structural metaphor, speakers "use one highly structured and clearly delineated concept to structure another" (Lakoff and Johnson, 1980: 61). When concepts that are difficult to explain take on importance in people's daily lives, there may be a need to talk about them metaphorically. Dobrovol'skij and Piirainen (2005: 142) hold that in such cases, speaking metaphorically helps to structure difficult situations that have just barely been structured thus far. They further argue that "the metaphor is therefore not just a means of naming, but an instrument of conceptualising the world" (Dobrovol'skij and Piirainen, 2005: 142).

In that way, the "homework" metaphor in particular simplifies complex economic situations such as the European debt crisis into one where everything would be fine if everyone just did their homework. Already in 1997, Rita Süssmuth, a German politician, criticised the "terrible simplifications" brought on by the use of the phrase "seine Hausaufgaben machen", which misleads the public into believing that a particular issue should be easy to solve:

Wenn komplizierteste ökonomische und strukturelle Vorbereitungen für die Weiterentwicklung der Europäischen Union unter die Floskel "seine Hausaufgaben machen" gestellt werden, muss die Öffentlichkeit glauben, auftretende Probleme seien lediglich von faulen und unaufmerksamen "Schülern" verschuldet. (Süssmuth, 1997)

['When highly complicated economic and structural preparations for further development of the EU are addressed by the set phrase "to do one's homework", the public has to believe that problems which occur are merely caused by lazy and unattentive students.'] (my translation)

It has been argued that structural metaphors can help fortify social and economic views (Holmgreen, 2003), partly because they are "persuasive efforts that encourage intersubjective agreement about how to see the world" (Schiappa, 2003: 129). The use of the "homework" metaphor serves to attach authority to the actor who sets the homework, while it portrays those who have to do the homework as inferior (Bernabeu García, 2012). The simplifying effect of the "homework" metaphor may thus be used deliberately to influence the public perception of a given issue. If metaphors are "exploited to suggest that a particular interpretation of events is the natural, inevitable interpretation" (Deignan, 2005: 130), the arguments of the authority setting the homework are presented as unchallengable.

However, the "homework" metaphor is not just a structural metaphor, but also a framing device. For the purposes of this article, I will use the term "framing" in the sense of "cognitive structures we think with" (Lakoff, 2008: 22), more specifically, the conceptualisation of an issue in a particular way by drawing on particular semantic 
fields or domains. Those conceptualisations always carry a stance towards the issue, so frames are never neutral (Lakoff 2008: 11-12; see also Chong and Druckman, 2007: 106; Sullivan, 2013: 17-20).

Drawing on a metaphor from the education source domain such as "homework" suggests that the speaker seeks to convey confidence in being correct about the issue under discussion, and asserts the moral right to "educate" others about it. This happens because the "homework" metaphor draws on already existing frames and values of the education source domain (on the integration of frames in theories of metaphor, see Sullivan, 2013), whereby homework is something that is not questioned, but simply needs to be done. If certain economic measures such as austerity are just presented as tasks to be done, the reader may be led to forget that these measures are controversial.

That phenomenon may be described as a shift in thinking and in behavior via "the arguments' reservoir" (Amossy, 2009: 263), by retrieving elements stocked in the collective memory of going to school. Such an educating context of communication may further support the choice of metaphors from this source domain (see the notion of "pressure of coherence" in Kövecses, 2009). In terms of the well-known strict father vs nurturant parent models of morality in politics (Lakoff, 2002), for instance, the "homework" metaphor would fit more adequately into a strict father model because homework is a duty to be done and as such non-negotiable.

If the "homework" metaphor is used to refer to economic development or remotely imposed measures to lower public debt, it combines two devices of figurative language: it is both metaphoric (referring to complex economic programs as schoolwork) and meiotic (understating the ramifications of implementing such an economic program). As such, the "homework" metaphor is a complex figurative frame, a concept defined as a combination of "metaphor, hyperbole, and/or irony" (Burgers et al., 2016: 411). As meiosis (understatement) is traditionally included along with metaphor, hyperbole and irony in the quality-based figures of speech exemplary of conversational implicature (Grice, 1989: 34; see also Taverniers, 2017: 325), extending the definition of complex figurative frames to include meiosis should be warranted.

As Burgers et al. (2016: 419) state, most studies investigate the use of individual figurative devices in isolation, whereas there are very few systematic investigations of combinations of figurative language devices. The few studies combining metaphor and hyperbole that do exist lead them to hypothesise that such frames "may have a large impact in steering public debates in the relatively short term, but lose their strength after some time" (Burgers et al., 2016: 420). The "homework" metaphor as a frame combining metaphor and meiosis, however, has enjoyed continued popularity and its gain in strength may also mean a gain in manipulative force.

Complex figurative frames should receive greater attention in metaphor research because they are

used as both framing and reasoning devices to shape the public's opinion on important topics by presenting a particular problem definition, cause and moral evaluation, and implying policy solutions (Burgers et al., 2016: 420421). 
Figurative frames are also hypothesised to have the greatest manipulative effect on participants with little political knowledge for whom the frame may be the only access to a problem they do not otherwise understand (Burgers et al., 2016: 424). As the "homework" metaphor shows, complex figurative frames contain "two rhetorical operations at the same time", which makes them "difficult for critics to challenge" (Burgers et al., 2016: 420-421). In that way their potential to manipulate the public discourse on important societal topics is far greater than that of simple frames or metaphors.

\section{Methodology}

The study draws on publicly available corpora of spoken and written political discourse. Corpora are a useful method to satisfy increasing demands to place "interdisciplinary metaphor research on a firm empirical footing, which implies that the results of our analyses can be verified and replicated" (Gibbs and Lonergan, 2009: 253). CharterisBlack (2004: 42) has argued that corpora can help "identify typical metaphorical uses of language" and interpret and explain such uses. Corpora have been used to analyse the connotations of idioms (Channell, 1999), and there has recently been some interest in the annotation of evaluative aspects of language use, which would allow the study of evaluation through corpora (Fuoli and Hommerberg, 2015; Fuoli, 2018).

The study of the English "homework" metaphor primarily draws on the newspaper parts of the Corpus of Historical American English (COHA, available at https://corpus.byu.edu/coha/) and the Corpus of Contemporary American English (COCA, available at https://corpus.byu.edu/coca/). The newspaper section of the COHA, which has a size of over 40 million words, as well as data from the Saturday Evening Post and TIME, which are included in the magazine section of the corpus, is analysed up to 1989. For the years 1990 until today, I analyse the newspaper section of the COCA, which features 113 million words between 1990 and 2017.

To inform the account of the emergence and spread of the metaphor by also including spoken English, I have additionally consulted the HANSARD corpus (available at http://www.hansard-corpus.org).The HANSARD is a 1.6 billion word corpus "of nearly every speech given in the British parliament from 1803-2005", according to the website. It represents oral language from the political sphere and is therefore useful to get an idea of the development of the metaphor in oral language.

As for the German "Hausaufgaben" metaphor, I draw on the ZEIT corpus, available through the website of the Digitales Wörterbuch der deutschen Sprache ('digital dictionary of the German language', https://www.dwds.de/r?corpus=zeit). Die ZEIT is a weekly German newspaper, publishing 52 issues per year. The corpus contains every issue from 1946 until today as well as online articles that only appeared on the website. In order to achieve a balanced amount of data for each year, I have excluded online articles from the analysis and only analysed printed articles for this study.

To identify figurative uses of the "homework/Hausaufgaben" metaphor reliably, I have adopted criteria employed by existing metaphor research. Dobrovol'skij and 
Piirainen (2005) propose two criteria: image requirement and additional naming. Image requirement is defined as

the synchronically identifiable ability of a linguistic unit to denote its referent not directly but via another concept. [...] It is a sign that uses the content of another sign as a form filled with new content. (Dobrovol'skij and Piirainen, 2005: 17)

Additional naming refers to the presence of a "more direct and cognitively simple expression denoting approximately the same entity" (Dobrovol'skij and Piirainen, 2005: 18). To be considered figurative, then, an expression should have "a (more or less strong) image and 'normal' synonyms, i.e. function as an additional naming" (Dobrovol'skij and Piirainen, 2005: 19, emphasis original).

A similar method to check for metaphoricity was set forth by Pragglejaz Group (2007). They propose that the meaning in context for each occurrence of the respective term should first be established. Once it has been shown that they do have more basic contemporary meanings in other contexts, it is decided whether "the contextual meaning contrasts with the basic meaning but can be understood in comparison with it" (Pragglejaz Group, 2007: 3).

The present analysis thus takes into account the context in each case to check "whether or not there is the semantic tension that justifies classification as metaphor" (CharterisBlack, 2004: 37). If so, that instance is counted for the analysis. In the case of the "Hausaufgaben" metaphor, the image is that of the definition given in the Duden dictionary. Non-figurative synonyms of the metaphorical meaning may be, depending on context, seine Pflicht/seinen Auftrag erfüllen ('to do one's work/duties'), sich vorbereiten ('to prepare') etc.

As mentioned before, the homework metaphor in English is already a conventionalised metaphor not strictly limited to the education context, which makes the application of the metaphor identification method outlined above problematic. In the analysis of the metaphor in English, I have therefore counted all those instances where the expression was used outside of a school context.

In addition to the quantitative analysis, I have also conducted a qualitative analysis of the data. To study the evaluative profile of the metaphor, it is necessary to find out to what extent it has been used for positive and negative representation of discourse participants and how this has evolved over time in the corpus under analysis. The "homework/ Hausaufgaben" metaphor is usually encountered in phrases stating that someone has or has not done it. While the function is usually to criticise some discourse participant for not having done their homework, the evaluative context (cf. Charteris-Black, 2004) may be slightly different, as demonstrated by the quote in (6) and the corpus example (7). In those examples, the "homework" metaphor is used to criticise someone else by distinguishing oneself for having done one's homework, unlike some other party.

(6) The EU's climate commissioner, Connie Hedegaard, said the agreement was an important step for the whole world. She said: "We have sent a strong signal to 
other big economies and all other countries: we have done our homework, now we urge you to follow Europe's example. (The Guardian, 24 October 2014)"

(7) Bezüglich der preislichen Wettbewerbsfähigkeit ist leider noch nicht viel passiert. [...] Allein Irland hat seine Hausaufgaben gemacht und seine Preise seit 2006, dem Zeitpunkt des Platzens der irischen Blase, gegenüber den Wettbewerbern in der Euro-Zone um 15 Prozent reduziert. (Die Zeit, Nr 4/2014)

['Not much has happened regarding price competitiveness. [...] Only Ireland has done its homework and reduced its prices in comparison to its competitors in the Eurozone when the Irish bubble burst in 2006.']

In the qualitative analysis of the development of the "homework" metaphor, then, I have established the following three different evaluative contexts:

- affirmative, which refers to a statement like $X$ has done their homework (see example (7))

- negative, which refers to a statement like X has not done their homework (see example (4))

- neutral, where the speaker just talks about the existence of homework without specifically saying whether or not it has been done by anyone (see example (2))

\section{Analysis of the evolution of the "homework" metaphor in English and German}

I will first discuss the appearance and development of the "homework" metaphor in English, based on the HANSARD corpus and the COHA/COCA corpus. The first occurrence of the metaphor in the HANSARD corpus is in 1936, shown in example (8).

(8) I read a speech by a member of the German Government the other day in which he referred to that questionnaire and said, "Really, is the German Government to be set homework?" (31 July 1936)

The word homework is taken out of a school context, applied to a collective rather than a person and also used with the verb set, so it seems pretty clear that the usage is metaphorical. The use of the "homework" metaphor increases in the 1960s, at which point it is commonly used as a way of criticising others' lack of preparation, as in examples (9-11).

(9) If the hon: Member for the Isle of Thanet does not know that, he had better do his homework. (13 April 1960)

(10) Yet, in all this intervening period of ten or 11 months, judging by what we have been told during the Second Reading, the Government have done no homework on this subject. (1 May 1961) 
(11) I do not think that people generally will readily accept what the right hon: Gentleman has just told us: He does not seem to have done his homework on the subject. (5 March 1963)

The increase in usage frequency leads to speakers' comments on the frequency of occurrence of this metaphor, as was already seen in example (1) above. After a peak in the 1960s and 1970s, the "homework" metaphor seems to have been in decline in the HANSARD corpus since then (see the data in Table 1).

Table 1. Occurrences by decade in the HANSARD and COHA/COCA corpora

\begin{tabular}{rrrrrrr}
\hline & & HANSARD & \multicolumn{4}{c}{ COHA/COCA } \\
decade & size & instances & per million & size & instances & per million \\
\hline $1930 \mathrm{~s}$ & 95190137 & 3 & 0.03 & 17084910 & 0 & 0 \\
$1940 \mathrm{~s}$ & 94846765 & 7 & 0.07 & 19397531 & 8 & 0.41 \\
$1950 \mathrm{~s}$ & 120964868 & 55 & 0.45 & 21018357 & 14 & 0.67 \\
$1960 \mathrm{~s}$ & 152041765 & 621 & 4.08 & 19932435 & 23 & 1.15 \\
$1970 \mathrm{~s}$ & 163341175 & 620 & 3.8 & 16673203 & 18 & 1.08 \\
$1980 \mathrm{~s}$ & 183732627 & 517 & 2.81 & 15774076 & 24 & 1.52 \\
$1990 \mathrm{~s}$ & 177125124 & 489 & 2.76 & 40122848 & 63 & 1.57 \\
$2000 \mathrm{~s}$ & 88449672 & $170^{3}$ & 1.92 & 39708241 & 55 & 1.39 \\
$2010 \mathrm{~s}$ & & & & 33164318 & $50^{4}$ & 1.51 \\
\hline
\end{tabular}

In the COHA/COCA corpus (also shown in Table 1), the first occurrences of the homework metaphor are in the 1940s, as shown in example (12). The metaphor starts to be used regularly from then onwards, initially at times marked as a metaphor by quotation marks, as in example (13), and used predominantly to refer to the preparation done by individuals (example 14).

(12) But the potential legal complications after World War II make the Russian claims look like a law schoolboy's homework. (TIME, 10 February 1941)

(13) He has done his "homework" carefully, and is expected to have some ideas of his own to put forward, notably on the subject of Palestine refugees. (Christian Science Monitor, 20 January 1956)

(14) The President has done his homework well and never needed to consult his advisers on positions. (New York Times, 7 June 1961)

From the 1980s onwards, it remains stable at a frequency of around 1.5 occurrences per million words and is used also to refer to non-individual discourse actors (example (5) above). Thus, based on the brief analysis of the metaphor in the HANSARD and the COHA/COCA corpus, it seems that the "homework" metaphor started being used with some frequency in both spoken and written English in Britain and the US in the 1960s and has since then become a stable metaphor in both spoken and written political discourse. 
Table 2. Occurrences by decade in the ZEIT corpus

\begin{tabular}{rrrrrrrr}
\hline decades & size & inst. & per mil. & decades & size & inst. & per mil. \\
\hline $1940 \mathrm{~s}$ & 6175180 & 0 & 0 & $1980 \mathrm{~s}$ & 57985982 & 47 & 0.81 \\
$1950 \mathrm{~s}$ & 23553605 & 0 & 0 & $1990 \mathrm{~s}$ & 62013185 & 109 & 1.76 \\
$1960 \mathrm{~s}$ & 41612812 & 0 & 0 & $2000 \mathrm{~s}$ & 83274119 & 154 & 1.85 \\
$1970 \mathrm{~s}$ & 46916344 & 10 & 0.21 & $2010 \mathrm{~s}$ & 67475779 & $129^{5}$ & 1.91 \\
\hline
\end{tabular}

Looking at the "Hausaufgaben" metaphor in German (see the data in Table 2), based on the ZEIT corpus, the first instance of metaphoric use is found in 1971, shown in example (15).

(15) Außerdem schwelt immer noch die Kontroverse um den dampfgekühlten Brüter, dessen Entwicklung 1969 abgebrochen worden war und über den im Dezember des vergangenen Jahres eine abschließende Studie vorgelegt werden sollte, die dann noch einmal hätte diskutiert werden können. Diese Hausaufgabe freilich konnte das Karlsruher Management nicht erledigen. (Die ZEIT, Nr 9/1971)

['Furthermore there is still a heated debate about the steam-cooled breeder reactor, whose development was put on hold in 1969 and about which a conclusive study was supposed to be produced in December last year, which could then have been discussed once more. This homework was of course not done by the Karlsruhe management.']

Examples (16-17) contain comments on the frequency of occurrence of the metaphor showing that it was firmly established in the 1990s.

(16) Während die vielgescholtenen Gewerkschaften sich zum realen Lohnverzicht bereitgefunden haben, ist der Staat seinen Beitrag noch schuldig geblieben. Die eigenen Hausaufgaben, wie der Bundeskanzler sich so gerne ausdrückt, stehen noch an. (Die ZEIT, Nr 7/1993, emphasis mine)

['While the much-scolded unions have agreed to the real wage sacrifice, the state still owes its contribution. Its own homework, as the chancellor so likes to say, still remains to be done.']

(17) Das Buch liest sich, wie Schröder spricht. Flapsig wird Politik als "Job" bezeichnet, ständig werden "Hausaufgaben" (ein Lieblingswort auch Helmut Kohls) angemahnt, und der Leser kann oft ein rhetorisches Schulterklopfen zwischen den Zeilen entdecken. (Die ZEIT, Nr 32/1998, emphasis mine)

['The book reads like Schröder talks. Politics is flippantly referred to as a "job", homework (also one of Helmut Kohl's favourite terms) is constantly called for and the reader can often notice a rhetorical pat on the back between the lines.'] 


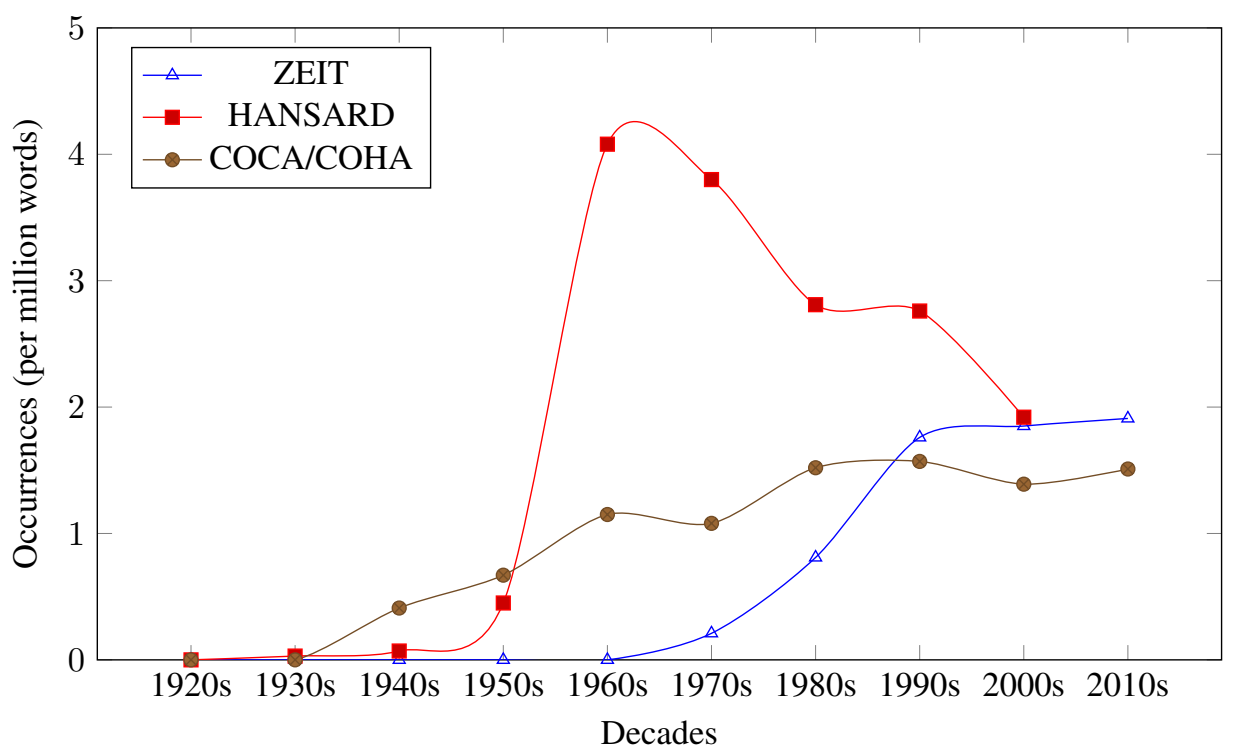

Figure 1. Comparison of the frequency of the "homework/Hausaufgaben" metaphor in the three corpora in instances per million words

A comparison of the changes in frequency of the "homework" metaphor in the HANSARD and COHA/COCA corpora, and of the "Hausaufgaben" metaphor in the ZEIT corpus is shown in Figure 1. In the German corpus, the metaphor enters common usage around twenty years after it did so in English discourse and at a somewhat greater pace. This may mean that the metaphorical use of the word Hausaufgaben was adopted from English political discourse. In recent decades, it also remains stable at a slightly higher frequency than that exhibited by the English data.

Some evidence for a potential overuse is provided by example (18), where the author quotes Bill Clinton in a speech given upon receiving the Karlspreis as having urged the Europeans to do their "unfinished homework".

(18) Selbstbewusst klingen auch die Kommentare zu Clintons Aachener Preisrede, in der er Amerika und Europa als "Modell” präsentierte, die Europäer aber auch drängte, ihre "unerledigten Hausaufgaben" zu machen. (Die ZEIT, Nr 24/2000)

['There are self-confident comments on Clinton's Aachen acceptance speech, in which he presented America and Europe as a "model", but also urged the Europeans to do their unfinished homework.']

While the expression is presented as a quote, what Clinton actually said was "unfinished business" . The official translation on the website of the Karlspreis has "unerledigte Aufgaben" ('unfinished tasks'). If neither the original speech nor the official German 
translation uses the "homework" or "Hausaufgaben" metaphor, it is interesting to ask why the journalist opted to use it. It may indicate, as noted by Kemper (2016), that the expression is becoming a set phrase in press articles.

It is perhaps a further sign of entrenchment that language users start using the expression in an idiosyncratic way or apply it to new contexts, as could be said to be the case with example (19). While usually the fact of having done one's homework is used as a praise, this example is an interesting extended use of the "Hausaufgaben" metaphor to indicate that someone has done something that is basic and expected and thus nothing special.

(19) Aus Schavans Amtszeit wird vor allem das Deutschlandstipendium in Erinnerung bleiben; Wanka beschränkte sich darauf, ihre Hausaufgaben zu erledigen wie etwa die Aufstockung des Hochschulpaktes. (Die ZEIT, Nr 38/2013)

['Regarding Schavan's time in office, people will remember mainly the Germany Bursary; Wanka limited herself to doing her homework such as the funding increase of the higher education agreement.']

The earlier occurrence of the metaphor in English is perhaps not surprising, given that standard dictionaries already treat the "homework" metaphor as a conventionalised metaphor, as mentioned above. Its early use in English seems to have been a collegial form of side swipe between members of parliament for whom debating and attacking each other is a type of sport (cf. the first use of the metaphor cited in the OED being in a sports context). Once it entered widespread use in the 1960s, contact with English texts may have prompted users of German to adopt the metaphor. If the ZEIT corpus is representative, the "Hausaufgaben" metaphor became widely used in German political discourse in the 1990s.

\section{Pragmatic effects of the "homework" metaphor}

To study the evaluative effects of the "Hausaufgaben" metaphor in some more depth, I have analysed three types of evaluative contexts as outlined in the methodology. The English data, shown in Figure 2, should be treated with some care because, as discussed at the outset of this paper, the "homework" metaphor is already conventionalised in English. From the data we may infer that it was first used as a metaphor for positive evaluation, as there are more affirmative uses than negative or neutral ones throughout the data. The neutral use seems to become the most frequently used context, and rises more steadily than the affirmative and positive uses, which argues for the establishment of the metaphor in discourse, as it is now enough for speakers to talk about homework without explicitly mentioning whether someone has or has not done it.

Figure 3 shows the development over time of the negative, affirmative and neutral uses of the "Hausaufgaben" metaphor in the ZEIT corpus. The metaphor is first used both in a neutral and negative way between 1980 and 1984. In the second part of that decade, affirmative statements involving this metaphor also begin to be used with some frequency. In the early 90s, the use of the metaphor in negative statements increases strongly and 


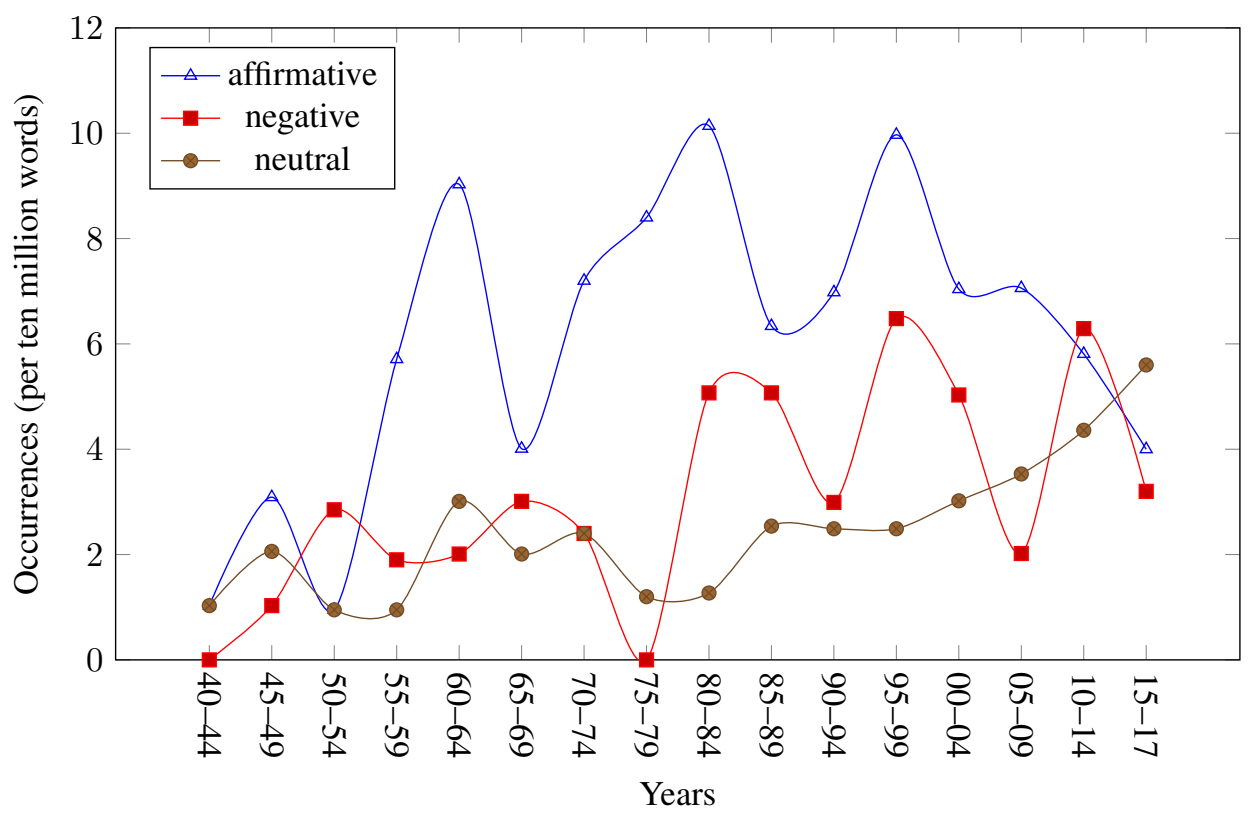

Figure 2. Development over time of affirmative, negative and neutral uses of the "homework" metaphor in the COHA and COCA corpus

remains high until the end of the 2010 s decade. In the first part of the present decade, it decreases notably, perhaps due to the negative perception among journalists discussed in the introduction to this paper. Affirmative and neutral contexts also steadily increase in frequency. Neutral contexts show a strong increase in the present decade and have become the most common usage.

The data is only available until 2016, so the findings for the years 2015-16 should be treated with care. Should they be accurate, however, it might show that through the raising of public awareness about the metaphor such as the "Unwort" campaign and negative press mentioned above the metaphor is now being used much less frequently in German than at its peak during the European debt crisis.

Overall, the most noticeable difference between the English and the German data is that, in English, the affirmative context (saying that someone has done their homework) seems to have been more popular, while in German, the metaphor has primarily been used to place blame on others by saying that they have not done their homework. With time, as the metaphor became more widely used, language users picked up the figurative frame and pre-empted the accusation by affirming that they had "done their homework", or they just talked about "homework" in general, thus firmly establishing the figurative meaning of the expression.

What both languages have in common is that the neutral use has been increasing and has in recent data been the most common use context. This means that speakers now use 


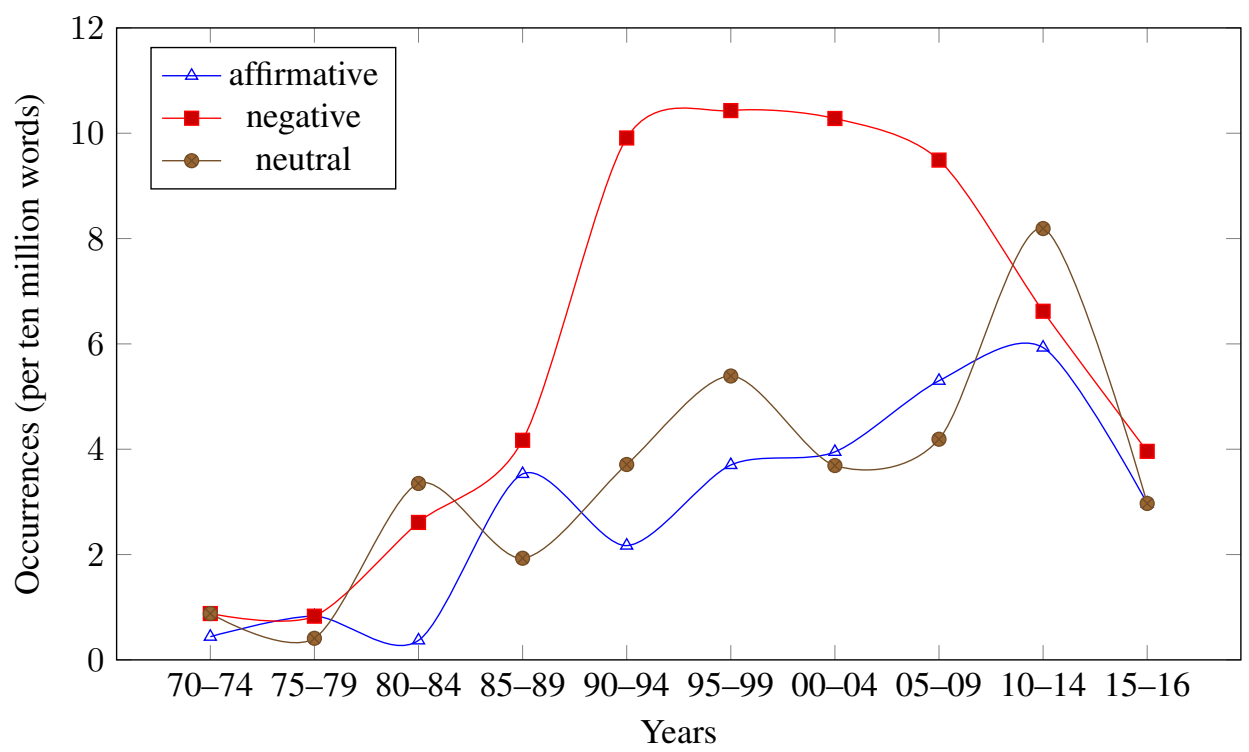

Figure 3. Development over time of affirmative, negative and neutral uses of the "Hausaufgaben" metaphor in the ZEIT corpus

the "homework" frame outside its original context of someone's having or not done their homework. It seems to be established enough to be used as a simple way of referring to issues in political debates.

While initially used as a mitigating choice, or "bush" (Caffi, 2007: 98), as a way to soften the criticism (see Martin and White, 2005: 138) of someone else's lack of preparation, today, the accusation of not having done one's homework is often seen in a somewhat different light. The scope of the metaphor has expanded to regularly refer also to larger groups or entities such as parties or countries. Partly affected by deteriorating diplomatic relations and differing power relations between countries in the recent crisis in Europe, it may be interpreted as a condescending way of levelling criticism at economically under-performing countries who choose not to agree to particular reforms or other activities that seem obvious to countries in better economic situations. Thus, if someone from country A says that country B has not done its homework, this usually implies that the tasks being referred to were indeed ordained by country A, or that country A at least fundamentally supports them.

Thus, it is not only the scope of what the metaphor refers to that has changed, but also its implications. While in the original mitigating context it was either not clear who set the homework or it was generally accepted that the task being referred to is something that should be done (such as preparations for a parliamentary debate), today the accusation of not having done the homework may imply in particular contexts that economic advice from an actor who assumes authority in the discourse was not heeded. The mitigating 
effect is thus lost, a possibility that is mentioned by Caffi (2007: 100) as a potential "cost" if the addressee of the expression feels treated condescendingly.

Wodak (2001) outlines some discourse strategies, defined as "more or less accurate and more or less intentional plan[s] of practices adopted to achieve a particular social, political, psychological or linguistic aim" (Wodak, 2001: 73). Some of the strategies for "positive self- and negative other presentation" (Wodak, 2001: 73) are applicable to what has been found for the use of the "homework" metaphor.

She defines a strategy called "referential/nomination" as the "construction of ingroups and out-groups" (Wodak, 2001: 73). The use of the "homework" metaphor may construct such groups, namely those who do their homework and those who do not, as in example (7) above. The speaker there differentiates between "good pupils" and "bad pupils", that is, those countries that have supposedly "done their homework", i.e. applied the reforms that the creditor countries ordained on them, and those countries, including Greece, which have not applied the reforms. This may undermine the solidarity among countries critical of the usefulness and appropriateness of the reforms because those countries are pitted against each other in a discourse of competition. It may also bolster populist movements in those countries by giving those movements the ability to present the people as victims, as is the case with Syriza in Greece (Stavrakakis and Katsambekis, 2014).

As a result of the construction of such out-groups, the related strategy of "argumentation" may be used for the "justification of positive or negative attributions" (Wodak, 2001: 73). Behaviour that may otherwise be considered unfair, for instance, would be justified by the allegation that someone has not done their homework, which may make punishments or sanctions seem acceptable rather than unfair. Such a process is exemplified in example (20).

(20) Alexis Tsipras's homework has been thrown back in his face. [...] Greece's creditors looked at the plan submitted by Alexis Tsipras to end his country's debt crisis and found it wanting. Like a teacher dealing with an obtuse pupil, the message in the revised document sent back to the Greeks was simple: this is a shoddy piece of work. Do it again. (The Guardian, 24 June 2015)

The use of the "homework" metaphor and other words from the education source domain in that example seems to justify the act of simply rejecting a potentially viable counterproposal by Alexis Tsipras without considering it further. As Greece's creditors belong to more powerful donor countries, the discourse used in the press sides with them and presents the Greeks as "obtuse pupils".

The strategy of "perspectivation/framing" positions the speaker's point of view (Wodak, 2001: 73) and the frame evoked by the word homework is that of school, where actors are reduced to bad or lazy pupils if they disagree, i.e. "do not do their homework". This strategy is related to "predication", defined as "labelling social actors more or less positively or negatively, deprecatorily or appreciatively" (Wodak, 2001: 73). The use of the metaphor is thus to disqualify particular actors through framing in discourse. 


\section{Figurative framing through the education source domain}

The use of the "homework" metaphor evokes the frame of "Education_teaching", defined as containing "words referring to teaching and the participants in teaching. A Student comes to learn either about a Subject; a Skill; a Precept; or a Fact as a result of instruction by a Teacher"7 . Within this frame, I would argue "homework" to be either a MATERIAL frame element ("Educational Material, such as books, tapes, or videos, used by a Teacher or a Student to acquire skills or knowledge") or a MEANS frame element ("An intentional action performed by the actor (Student or Teacher depending on the profiling of particular words) that lets them achieve the instruction or learning they are attempting").

Metaphors other than "homework" belonging to the education source domain, such as "model pupil" and "class", widely occur in press articles in different languages, as demonstrated in examples (21-23).

(21) In many ways, indeed, Spain is behaving like a model pupil of German chancellor Angela Merkel. (The Guardian, 9 June 2012, emphasis mine)

(22) Antes de la crisis, España era el alumno modelo de la clase de Maastricht, con un superávit público del 2,2\% y un endeudamiento por debajo del $40 \%$ del PIB. (Nuevatribuna.es, 7 January 2012, emphasis mine)

['Before the crisis, Spain was the model pupil of the Maastricht class, with a public surplus of $2.2 \%$ and a debt of less than $40 \%$ of GDP.']

(23) Bereits seit Mai 2014, früher als geplant, kann sich Lissabon wieder aus eigener Kraft finanzieren. In Brüssel und Berlin gelten die Portugiesen deshalb als Musterschüler, zusammen mit Irland. (Die ZEIT, $\mathrm{Nr}$ 41/2015, emphasis mine)

['Already since May 2014, earlier than planned, Lissabon can finance itself autonomously. That's why in Brussels and Berlin the Portuguese, along with Ireland, are seen as model pupils.']

The proliferation of metaphors evoking an education frame may be to some extent driven by the widespread use of the "homework" metaphor, which makes discourse participants look for related terms to remain in the frame. This would support the hypothesis that "figurative frames boost frame salience" (Burgers et al., 2016: 423): speakers use the education frame when thinking about the target concept, which brings up related words that are used as metaphors.

We have seen earlier that metaphors discussing the current state of a crisis such as the European debt crisis are usually drawn from the health or nature source domains. Markwardt (2015) argues that such metaphors have a more subversive effect than open insults such as the BILD tabloid's infamous "Pleite-Griechen" ('Broke Greeks', see Tsatsos, 2011). That is because insults can be recognised as such and rebuffed, while metaphors work on a more subconscious level, for example converting monetary obligation into moral obligation (Markwardt, 2015). 
Discourse on the solutions to the crisis, on the other hand, often draws on the domestic economy ("Swabian housewives") or education source domains ("doing homework", "learning lessons") (Markwardt, 2015). Those metaphors have in common that they construct the discourse by evoking a student-teacher dichotomy, establishing differential power relations between the discourse participants and framing political negotiation in terms of a classroom situation. Such framing also entails bypassing questions of whether, for instance, a particular reform package is fair, appropriate or well-designed for a particular country. Such considerations disappear if that package is presented simply as "homework" because that expression evokes the connotations of work that is necessary and thus not questioned but just done.

The investigation of the "homework" metaphor and its manipulative potential begun in this paper intends to open a variety of possibilities for further research. If the findings of this study are indicative of a growing popularity of the education source domain, at least in German discourse, this may support the idea that the frequency of occurrence of a metaphor depends on a discourse community's conventional thought patterns (Boers and Demecheleer, 1997: 117). The "homework" metaphor may be particularly popular in the German discourse community because of a widespread assumption among politicians that Germany has done something correctly in terms of economic management, such as Germany's success in the "economic miracle" (Fulbrook, 2002: 147-151) and of recent reforms such as Hartz IV. Such a view is discussed, for instance, by Marquand (2011):

Much of the recent breakout [of its postwar identity] is due to a rising German industrial base achieved by elbow grease, niche market savvy, and, as is often said here, by "doing our homework." [...] Germany's concerted effort to build a panoply of world-competitive firms is one reason the public here has objected so strongly to bailouts of other EU nations, notably Greece and possibly Portugal. Germans value hard work and sacrifice, and they have little patience with those who they feel don't share the same ethic. "We put a lot of pressure on ourselves to do our homework," says a senior German economic official. "We expect others to do their homework as well, and when they don't, it doesn't sit well here..."

There may thus be a conviction that other countries should learn from and follow this model. The "homework" metaphor should be studied in other languages in order to investigate whether and how it has been adopted in other discourse communities, especially those in Southern Europe that have been the target of economic reforms and criticism in the European debt crisis.

In countries such as Spain, the metaphor is certainly found among the frequent expressions in political discourse, perhaps partly through its extensive use by foreign politicians and media throughout the crisis. Example (2) above and the headline in example (24) show that the metaphor already seems to be entrenched enough in Castillian and Catalan Spanish to be used in a general context, without specifying whether or not someone has done their homework.

(24) A Europa li costa fer els deures. (Ara, 11 February 2016) 
['Europe has trouble doing its homework.']

This may be some indication for a base of metaphors that is drawn on cross-linguistically in political discourse. The frequent use of the "homework" metaphor in public discourse about important events such as the Euro crisis or the US presidential election may support the hypothesis that "figurative frames are used more often in public debates where the status quo is under discussion" (Burgers et al., 2016: 422).

The study of the "homework" metaphor is just at its beginning, and further systematic research is necessary to investigate the contexts where the metaphor commonly appears, and to perhaps discover further metaphors from the education source domain in a variety of languages. The present study has found some evidence that the "homework" metaphor has been firmly established since the 1990s and enjoyed especial popularity in recent crises. More recent corpus data is thus necessary to reliably study the use of this metaphor in other languages. But given the simplifying and manipulative force of the "homework" metaphor outlined in this paper, its cross-linguistic use as a normal way of referring to issues of public interest such as economic reforms may be problematic.

\section{Acknowledgements}

I am indebted to an anonymous peer reviewer for their comprehensive and constructive criticism of the first draft of my paper and for bringing to my attention a range of highly interesting references.

\section{Author biography}

Mario Bisiada is a tenure-track professor at the Universitat Pompeu Fabra in Barcelona (Spain), where he is a member of the Translation \& Discourse Studies Research Group. He received his PhD in Translation and Intercultural Studies from the University of Manchester (UK) for a study of the effect of translation from English on the use of hypotactic and paratactic constructions in German business articles. Recent publications include articles on the influence of editors on nominalisations and the passive voice in translated language, sentence splitting in translation and contact-induced language change in translation.

\section{Funding}

This work is part of the ModevigTrad (Evidentiality and epistemicity in texts of evaluative discourse genres. Contrastive analysis and translation) project, funded by the Spanish Ministerio de Economía y Competitividad (grant number FFI2014-57313-P).

\section{Notes}

1. 'Task given by the teacher that the pupils have to do at home' (my translation), http://www.duden.de/rechtschreibung/Hausaufgabe

2. 'Exercise given to students in the early stages of education to be done outside of class in order to complement what was learnt in class' (my translation)

3. Data only available until 2005

4. Data only available until 2017

5. Data only available until 2016 
6. See the original speech transcript available at http://www.karlspreis.de/en/laureates/williamjefferson-bill-clinton-2000/speech-by-bill-clinton, and the official translation at http://www.karlspreis.de/de/preistraeger/william-jefferson-bill-clinton-2000/rede-vonbill-clinton

7. See https://framenet2.icsi.berkeley.edu/fnReports/data/frameIndex.xml?frame=Education_teaching

\section{References}

Amossy R (2009) Argumentation in discourse: A socio-discursive approach to arguments. Informal Logic 29(3): 252-267.

Arrese Á (2015) Euro crisis metaphors in the Spanish press. Communication \& Society 28(2): 19-39.

Bernabeu García I (2012) El lenguaje de la crisis: "Hacer los deberes" no es cosa de niños. Available at: http://ponss.blogs.uv.es/2012/05/15/hacer-los-deberes-no-es-cosa-de-ninos/. (Accessed 6 March 2018).

Boers F and Demecheleer M (1997) A few metaphorical models in (Western) economic discourse. In: Liebert WA, Redeker G and Waugh LR (eds.) Discourse and Perspective in Cognitive Linguistics. Amsterdam: John Benjamins, pp. 115-129.

Burgers C, Konijn EA and Steen GJ (2016) Figurative framing: Shaping public discourse through metaphor, hyperbole, and irony. Communication Theory 26(4): 410-430.

Caffi C (2007) Mitigation. Amsterdam: Elsevier.

Channell J (1999) Corpus-based analysis of evaluative lexis. In: Hunston S and Thompson G (eds.) Evaluation in Text: Authorial Stance and the Construction of Discourse. Oxford: Oxford University Press, pp. 38-55.

Charteris-Black J (2004) Corpus Approaches to Critical Metaphor Analysis. Basingstoke: Palgrave Macmillan.

Charteris-Black J and Ennis T (2001) A comparative study of metaphor in Spanish and English financial reporting. English for Specific Purposes 20(3): 249-266.

Charteris-Black J and Musolff A (2003) "Battered hero" or "innocent victim"? A comparative study of metaphors for euro trading in British and German financial reporting. English for Specific Purposes 22(2): 153-176.

Chong D and Druckman JN (2007) Framing theory. Annual Review of Political Science 10(1): 103-26.

Cortés de los Ríos ME (2010) Cognitive devices to communicate the economic crisis: An analysis through covers in The Economist. Ibérica 20(1): 81-106.

Deignan A (2005) Metaphor and Corpus Linguistics. Amsterdam: John Benjamins.

Dobrovol'skij D and Piirainen E (2005) Figurative Language: Cross-Cultural and Cross-Linguistic Perspectives. Amsterdam: Elsevier.

Fulbrook M (2002) History of Germany 1918-2000: The Divided Nation. Oxford: Blackwell. Fuoli M (2018) A step-wise method for annotating APPRAISAL. Functions of Language 25(2).

Fuoli M and Hommerberg C (2015) Optimising transparency, reliability and replicability: Annotation principles and inter-coder agreement in the quantification of evaluative expressions. Corpora 10(3): 315-349. 
Gibbs RW and Lonergan JE (2009) Studying metaphor in discourse: Some lessons, challenges and new data. In: Musolff A and Zinken J (eds.) Metaphor and Discourse. Basingstoke: Palgrave Macmillan, pp. 251-261.

Grice P (1989) Studies in the Way of Words. Cambridge, Mass.: Harvard University Press.

Herrera Soler H (2008) A metaphor corpus in business press headlines. Ibérica 15(1): 51-69.

Holmgreen LL (2003) Setting the neo-liberal agenda: How metaphors help shape socio-economic realities. metaphorik.de 5(1): 90-114.

Janich N (2015) Sprachkritische Aktion: Unwort des Jahres. Available at: www.unwortdesjahres. net. (Accessed 6 March 2018).

Kemper A (2016) Haben Sie schon Ihre Hausaufgaben gemacht? Eine Formulierung wird zur Floskel. Zeit-Magazin 20: 42.

Kreuz RJ, Kassler MA and Coppenrath L (1998) The use of exaggeration in discourse: Cognitive and social facets. In: Fussell SR and Kreuz RJ (eds.) Social and Cognitive Approaches to Interpersonal Communication. New York: Psychology Press, pp. 91-111.

Kövecses Z (2009) Metaphor, culture, and discourse: The pressure of coherence. In: Musolff A and Zinken J (eds.) Metaphor and Discourse. Basingstoke: Palgrave Macmillan, pp. 11-24.

Lakoff G (2002) Moral Politics: How Liberals and Conservatives Think. Chicago: The University of Chicago Press.

Lakoff G (2008) The Political Mind: A Cognitive Scientist's Guide to Your Brain and its Politics. London: Penguin.

Lakoff G and Johnson M (1980) Metaphors We Live by. Chicago: University of Chicago Press.

Markwardt N (2015) Im Metaphernsalat der Krise. Available at: hrefhttp://www.zeit.de/kultur/ 2015-06/griechenland-krise-metaphern-sprache. (Accessed 6 March 2018).

Marquand R (2011) Germany - the new mini-superpower. Available at: https://www.csmonitor. com/World/Europe/2011/0130/Germany-the-new-mini-superpower. (Accessed 6 March 2018).

Martin JR and White PRR (2005) The Language of Evaluation: Appraisal in English. Basingstoke: Palgrave Macmillan.

O'Mara-Shimek M, Guillén-Parra M and Ortega-Larrea A (2015) Stop the bleeding or weather the storm? Crisis solution marketing and the ideological use of metaphor in online financial reporting of the stock market crash of 2008 at the New York Stock Exchange. Discourse \& Communication 9(1): 103-123.

Pragglejaz Group (2007) MIP: A method for identifying metaphorically used words in discourse. Metaphor and Symbol 22(1): 1-39.

Rojo López AM and Orts Llopis MÁ (2010) Metaphorical pattern analysis in financial texts: Framing the crisis in positive or negative metaphorical terms. Journal of Pragmatics 42(12): $3300-3313$.

Schiappa E (2003) Defining Reality: Definitions and the Politics of Meaning. Carbondale: Southern Illinois University Press.

Schuler K (2015) "Der Grieche hat genug genervt". Available at: http://www.zeit.de/politik/ deutschland/2015-07/griechenland-strobl-union. (Accessed 6 March 2018).

Semino E (2002) A sturdy baby or a derailing train? Metaphorical representations of the euro in 
British and Italian newspapers. Text \& Talk 22(1): 107-139.

Stavrakakis Y and Katsambekis G (2014) Left-wing populism in the European periphery: The case of SYRIZA. Journal of Political Ideologies 19(2): 119-142.

Sullivan K (2013) Frames and Constructions in Metaphoric Language. Amsterdam: John Benjamins.

Süssmuth R (1997) Vor der Bewährung: Der Bundestag in rauen Zeiten. Die Zeit 10: 3.

Taverniers M (2017) Metaphor in pragmatics. In: Barron A, Gu Y and Steen G (eds.) The Routledge Handbook of Pragmatics. London: Routledge, pp. 323-340.

Tsatsos A (2011) Working in Southern Europe in times of crisis: Myths and demons. Available at: https://mpra.ub.uni-muenchen.de/id/eprint/45237. (Accessed 6 March 2018).

Wodak R (2001) The discourse-historical approach. In: Wodak R and Meyer M (eds.) Methods of Critical Discourse Analysis. London: Sage, pp. 63-94. 